\title{
STATUS OF IMPLEMENTATION OF SYSTEM APPLICATION AND PRODUCT IN DATA PROCESSING ENTERPRISE RESOURCE PLANNING SYSTEM
}

\author{
C. H. Koc \\ Graduate School, Lyceum of the Philippines University, Batangas City, \\ Philippines
}

\begin{abstract}
This study generally assessed the status of system implementation of the System Application and Product (SAP) in data processing Enterprise Resource Planning (ERP) system in Universal Robina Corporation Calamba Plant. The result of this study could become a basis to propose strategies to enhance the effectiveness of SAP ERP system in Universal Robina Corporation Calamba Plant. The descriptive method was utilized in the conduct of study. The study revealed that the users of the system are satisfied with the SAP ERP system and that it is effective with respect to system implementation and performance. It was also found out that there is a significant difference exists and the respondents have assessed their effectiveness in the use of SAP ERP system when grouped according to demographic profile variable to be different.
\end{abstract}

Keywords: SAP ERP, implementation, performance.

\footnotetext{
${ }^{*}$ Corresponding author.

E-mail address: kocchh@yahoo.com.ph (C. H. Koc).
}

Copyright ( $) 2016$ Scientific Advances Publishers

2010 Mathematics Subject Classification: 68.

Submitted by Zeki Kasap.

Received March 20, 2016 


\section{Introduction}

The businesses and organizations need one or more information solution to manage and optimize company's business operations and store important data. In accordance, most manufacturing firms adopted information technology such as Enterprise Resource Planning (ERP) software and system to accomplish their business transactions and data processing needs. These technology intensified systems are worthwhile investment that will surely boost the business performance.

Enterprise Resource Planning (ERP) is comprised with different modules to support business activities such as finance, sales distribution, production, and human resources. All functional departments that are involved in operations or production are integrated in one system. An ERP system provides the common database and communicates needed actions that coordinate operations across different functional areas, and with customers and vendors involved in the supply chain (Tenkorang \& Helo [8]).

ERP system facilitates the integration of information by utilizing a central data repository allowing effective use of information by different parts within an organization (Laudon \& Laudon [5]). It integrates all functions and departments across an organization into a single, integrated computer system based on a centralized common database, so that the requirements of various departments of a business organization can be achieved (Arachchi [1]).

ERP system could help firms integrate inventory data with financial, accounting, production, sales, and human resources, and achieve seamless data and business process integration in their back offices in a wide range of tangible and intangible, qualitative and quantitative, benefits at the operational, managerial, strategic and organizational levels (Laudon \& Laudon [5]; Peng \& Nunes [6]; Prokopiev and Sevostianov [9]; Wei et al. [10]). Peng and Nunes [6] also argued that 
even though ERP systems had been successfully implemented, it did not mean that the "go-live" ERP system could guarantee the success of the ERP journey. In opposite, the post-implementation of the ERP system became the real challenge for managing the firm resources.

Major problem with the existing ERP system is the misfit between delivered functionality from the vendor and the needed functionality in the receiving end -customer organization. Johansson [3] mentions increased implementations costs leading to unwillingness to customize the system to the business processes and inadequate processes of defining the business requirements. Furthermore, Johansson [3] amongst other pain points mentions deficiency in the implementation process and huge variations in customer requirements and restates the problem that ERP systems are not closely enough related to the business processes they are supposed to be support (Johansson [3]).

Sudzina and Johansson [4] mention that it is a basic problem with the development of ERP systems that those who identifies the business needs often is different from those doing the development and see this as the main reason for the misfit between the delivered and need functionality.

Successful ERP implementation has been influenced by ERP implementation approach and the organization maturity level. Technology is only one aspect in ERP implementation other than people and process that have to be considered. ERP system will have high possibility of success, when the organization does the minimum change on organization's business process and software. However, this approach will make ERP system as a supporting operational on organization rather than creating a competitive advantage (Dantes \& Hasibuan [2]).

Universal Robina Corporation engages in a wide range of foodrelated businesses, including the manufacture and distribution of branded consumer foods, commodities and agro industrial business of farms. Branded consumer food has fourteen plants and one of this is Universal Robina Corporation Calamba Plant which is located at KM 50 
San Cristobal Calamba, Laguna. As of this March 1, 2015, it has 404 regular employees which 85 of them are the user of SAP ERP system. Universal Robina Corporation is one of the large organizations that adopt ERP system in the late of year 2010. The system in Universal Robina Corporation is defined as a unified business system that provides all business functions from the end-to-end business process, a real time executive environment. The company believes with the use of ERP system transaction processing and report generating programs result into fast and accurate data processing.

The ERP system integrates all functions and departments across an organization into a single, integrated computer system based on a centralized common database, so that the requirements of various departments of a business organization can be achieved. Universal Robina Corporation has implemented different modules such as materials management (MM), production planning (PP), quality management (QM), sales and distribution (SD), financial and controlling (FICO), human resource (HR), and preventive maintenance (PM), all these were meant to further enhance transaction and optimize the business process.

This study aimed to know what the SAP ERP needed to enhance the record keeping and generate accurate report to make easier for employees to do their job. This study also assessed the effectiveness of SAP ERP in Universal Robina Corporation Calamba Plant. The findings of this study could provide basis to enhance the SAP ERP system in Universal Robina Corporation Calamba Plant.

\section{Objectives of the Study}

This study aimed to determine the status of implementation of System Application and Products (SAP) in data processing Enterprise Resource Planning (ERP) system in Universal Robina Corporation Calamba Plant. 
More specifically, the study intended to describe the demographic profile of the employees in terms of age, gender, civil status, educational attainment, years of experience using the ERP system, department and module of SAP ERP being use, to measured the status of system implementation; system performance and level of effectiveness of SAP ERP; identified the common problems encountered by the employees on the use of the software; tested if there is significant differences on the effectiveness of SAP ERP in Universal Robina Corporation when the respondents are grouped according to socio demographic variable and proposed strategies to enhance the effectiveness of the SAP ERP system.

\section{Method}

\subsection{Research design}

The study use descriptive method of research. Descriptive research pertains to events which are recorded, described, interpreted, analyzed, and compared. Its objective is to describe systematically a situation, condition or area of interest. Quantitative method was also used in order to get the most factual and dependable information.

\subsection{Participants}

The respondents of the study included all 85 or 100\% regular employees from different department logistics, production, maintenance, quality assurance, sales and distribution, accounting, and preventive maintenance of Universal Robina Corporation at Calamba Plant, Laguna, Philippines who uses SAP ERP system in their work place. The study opted to choose the regular employees since they are better equipped to describe the effectiveness of the system. The census sampling design was used since the population size is manageable so everybody was made respondents of the study.

\subsection{Instruments}

The researcher reviewed questionnaires from online sources, modified the instruments used by other studies and collated these to have an instrument appropriate to her study. To validate the content and 
presentation of the questionnaire, interview with the users of SAP ERP was conducted and they were given to adviser and statistician for comments and suggestions. The questionnaires were distributed to regular employees of URC Calamba Plant to gather data and information needed.

The instrument has five parts; the first part of the questionnaire is on the profile of the respondents as age, gender, civil status, educational attainment, years of experience using SAP ERP system, department, and functional module of SAP was used for carrying daily transaction; the second part is about status of implementation of SAP ERP; third, status of system performance of SAP ERP while the fourth part contains level of effectiveness of SAP ERP system and fifth part is problems encountered.

\subsection{Procedure}

A letter of request to conduct the study was sent to the office of Human Resource Management. Eighty five (85) questionnaires were distributed personally to the regular employees of Universal Robina Corporation. This happened for three days. All participants returned the questionnaires representing rating of $100 \%$. After the retrieval of the questionnaires, the researcher started organizing the data and was submitted to the Research Center of Lyceum of the Philippines University-Batangas for tabulation and statistical treatment which serve as a basis in the analysis and discussion.

\subsection{Data analysis}

All data were gathered, tallied, encoded and statistically analyzed and interpreted using descriptive statistics which includes frequency distribution and ranking to identify the profile of the respondents and weighted mean to determine the status of the implementation of SAP ERP in Calamba Plant. The data were supported by using SPSS version to further analyze the result. 
The given scale was used to interpret and analyze the result of the study: 3.50-4.00: Strongly Agree (SA); 2.50-3.49: Agree (A); 1.50-2.49: Disagree (D); 1.00-1.49: Strongly Disagree (SD). In terms of effectiveness, the given scale was used: 3.50-4.00: Highly Effective (HE); 2.50-3.49: Effective (E); 1.50-2.49: Less Effective (LE); 1.00-1.49: Not Effective (NE). In terms of interpreting the problems encountered, the given scale was followed: 3.50-4.00: Always (A); 2.50-3.49: Often (O); 1.50-2.49: Sometimes (S); 1.00-1.49: Never (N).

\section{Results and Discussion}

Table 1 presents the percentage distribution of the respondents' profile. In terms of age, most of them are of 31 to 40 years old which comprise of 50.60 percent of the respondents. The least in the percentage is below 21 years old which comprise of 1.20 percent of the respondents. With regards to gender, the respondents are mostly female which obtained a frequency of 50 or 58.80 percent while 35 or 41.20 percent are male. The civil status of the respondents reveals that 45 or 52.90 percent are single while 40 or 47.10 percent are married. In terms of highest educational attainment, all employees are holders of bachelor's degree with about 85 or 100 percent.

The distribution of respondents according to their years of experience to reveals that 31 or 36.50 percent of the respondents used SAP ERP system. There are 21 or 24.70 percent who have one year experience. Majority of the respondents are from production department which comprise 40 or 47.10 percent. The least are from accounting department which comprises 3 or 3.50 percent.

The finding shows that majority of the respondents are from

production department, mostly female, working for 3 to 4 years, and qualified in their respective position as they are all degree holders. 
Table 1. Distribution of respondents according to profile $(\mathrm{N}=85)$

\begin{tabular}{|c|c|c|c|}
\hline Profile & & $\mathbf{f}$ & $\%$ \\
\hline \multirow[t]{5}{*}{ Age } & Below 21 & 1 & 1.20 \\
\hline & 21 to 30 & 30 & 35.30 \\
\hline & 31 to 40 & 43 & 50.60 \\
\hline & 41 to 50 & 10 & 11.80 \\
\hline & Above 50 & 1 & 1.20 \\
\hline \multirow[t]{2}{*}{ Gender } & Male & 35 & 41.20 \\
\hline & Female & 50 & 58.80 \\
\hline \multirow[t]{2}{*}{ Civil Status } & Single & 45 & 52.90 \\
\hline & Married & 40 & 47.10 \\
\hline \multirow[t]{2}{*}{$\begin{array}{l}\text { Educational } \\
\text { Attainment }\end{array}$} & Bachelor Degree & 85 & 100.00 \\
\hline & Below 1 & 21 & 24.70 \\
\hline \multirow{3}{*}{$\begin{array}{c}\text { Years of } \\
\text { Experience }\end{array}$} & 1 to 2 & 19 & 22.40 \\
\hline & 3 to 4 & 31 & 36.50 \\
\hline & 4 and above & 14 & 16.50 \\
\hline \multirow[t]{7}{*}{ Department } & Logistics & 11 & 12.90 \\
\hline & Production & 40 & 47.10 \\
\hline & Quality Assurance & 11 & 12.90 \\
\hline & Dispatch Center & 8 & 9.40 \\
\hline & Accounting & 3 & 3.50 \\
\hline & Human Resource & 4 & 4.70 \\
\hline & Maintenance & 8 & 9.40 \\
\hline \multirow[t]{7}{*}{ Module } & Material Management & 11 & 12.90 \\
\hline & Production Planning & 40 & 47.10 \\
\hline & Quality Management & 11 & 12.90 \\
\hline & Sales and Distribution & 8 & 9.40 \\
\hline & Financial \& Controlling & 3 & 3.50 \\
\hline & Human Resource & 4 & 4.70 \\
\hline & Preventive Maintenance & 8 & 9.40 \\
\hline
\end{tabular}


Table 2 shows the status of system implementation of SAP ERP in Universal Robina Corporation Calamba Plant. Based from the result, respondents agreed that the enumerated statements were achieved regarding the implementation of the system with a composite mean of 3.13. Having the highest weighted mean score of 3.79, respondents strongly agreed through continuous training the users will have deeper understanding about the system. On the other hand, with the lowest mean 2.81, respondents agreed that adopting with the changes by the new software can be easily attained.

From the below result, respondents agreed that the most effective way of implementing a system is to provide extensive technical trainings. In URC End User Training (EUT) is done before any implementation of every project and also SAP refresher course is in yearly basis to provide users with the knowledge they need to become more efficient and productive and to fully utilize the new or upgraded SAP system. Training is one of the most important aspects of any project. This helps increased user knowledge about the system, greater user commitment and user acceptance. Confusion and inaccuracy can be occurred if users are not trained to use the system in a proper way (Arachchi [1]). 
Table 2. Status of system implementation of SAP ERP in Universal Robina Corporation Calamba Plant

\begin{tabular}{|c|c|c|c|c|}
\hline & Indicators & WM & VI & Rank \\
\hline 1. & $\begin{array}{l}\text { End-users involved in the } \\
\text { requirements analysis, testing } \\
\text { and approval process }\end{array}$ & 2.95 & A & 8 \\
\hline 2. & $\begin{array}{l}\text { Evaluate the system to ensure } \\
\text { readiness in using the software }\end{array}$ & 3.00 & $\mathrm{~A}$ & 7 \\
\hline 3. & $\begin{array}{l}\text { The system is thoroughly tested } \\
\text { and accepted by the users }\end{array}$ & 3.12 & A & 6 \\
\hline 4. & $\begin{array}{l}\text { Provides technical and functional } \\
\text { business process trainings before } \\
\text { the actual use of the software }\end{array}$ & 3.13 & A & 5 \\
\hline 5. & $\begin{array}{l}\text { Proper orientation about the new } \\
\text { concepts being implemented }\end{array}$ & 3.18 & $\mathrm{~A}$ & 3 \\
\hline 6. & $\begin{array}{l}\text { Motivate users to have deeper } \\
\text { understanding about the system } \\
\text { through continuous training }\end{array}$ & 3.79 & SA & 1 \\
\hline 7. & $\begin{array}{l}\text { There is complete awareness of the } \\
\text { major process redesigned caused } \\
\text { by the new software }\end{array}$ & 2.92 & A & 9 \\
\hline 8. & $\begin{array}{l}\text { Easily adopt with the changes } \\
\text { brought by the new software }\end{array}$ & 2.81 & A & 10 \\
\hline 9. & $\begin{array}{l}\text { ISD entertain users in all times } \\
\text { regarding difficulties } \\
\text { encouragement }\end{array}$ & 3.26 & A & 2 \\
\hline \multirow[t]{2}{*}{10.} & $\begin{array}{l}\text { Business process was properly } \\
\text { scoped and was aligned } \\
\text { accurately in the system }\end{array}$ & 3.16 & $\mathrm{~A}$ & 4 \\
\hline & Composite Mean & 3.13 & $\mathbf{A}$ & \\
\hline
\end{tabular}

Table 3 reveals that the respondents agreed that SAP software execute a lot of functions that contributes to the production process of the company with a composite mean of 3.01. Having the highest weighted mean of 3.74, respondents agreed that it serves as a perfect tool in tracking transaction across various departments. This shows that the transaction reports of the system can be retrieved when needed. The 
system is agreed to automatically fills customers orders, with lowest mean of 2.76. From the result, SAP ERP systems are able to keep track of transaction more easily and coordinate other related departments with them across many different locations at the same time.

Table 3. Status of system performance of SAP ERP in Universal Robina Corporation Calamba Plant

\begin{tabular}{|c|c|c|c|c|}
\hline \multicolumn{2}{|c|}{ Indicators } & \multirow{2}{*}{$\begin{array}{l}\text { WM } \\
3.24\end{array}$} & \multirow{2}{*}{$\frac{\text { VI }}{\mathrm{A}}$} & \multirow{2}{*}{$\frac{\text { Rank }}{1}$} \\
\hline 1. & $\begin{array}{l}\text { Serves as a perfect tool in tracking } \\
\text { transaction }\end{array}$ & & & \\
\hline 2. & $\begin{array}{l}\text { Sustain the tracking of the amounts } \\
\text { of inventory }\end{array}$ & 3.20 & $\mathrm{~A}$ & 2 \\
\hline 3. & $\begin{array}{l}\text { Keeps record of the inventory and } \\
\text { supplies, and controls inventory } \\
\text { levels on a timely basis }\end{array}$ & 3.12 & $\mathrm{~A}$ & 3 \\
\hline 4. & $\begin{array}{l}\text { Enhances the maintenance of vendor } \\
\text { records and strengthens the } \\
\text { relationship with suppliers }\end{array}$ & 2.91 & $\mathrm{~A}$ & 9 \\
\hline 5. & $\begin{array}{l}\text { Serves as the best and in forecasting } \\
\text { purchases }\end{array}$ & 2.94 & $\mathrm{~A}$ & 6.5 \\
\hline 6. & $\begin{array}{l}\text { Monitors and controls inventory in } \\
\text { the most accurate way. }\end{array}$ & 3.08 & A & 4 \\
\hline 7. & $\begin{array}{l}\text { Controls and coordinates the } \\
\text { production process smoothly }\end{array}$ & 2.95 & $\mathrm{~A}$ & 5 \\
\hline 8. & Provides appropriate input for budget & 2.93 & $\mathrm{~A}$ & 8 \\
\hline 9. & Automatically fills customers orders & 2.76 & A & 10 \\
\hline \multirow[t]{2}{*}{10.} & $\begin{array}{l}\text { Keep tract on goods and services } \\
\text { regularly }\end{array}$ & 2.94 & A & 6.5 \\
\hline & Composite Mean & 3.01 & $\mathbf{A}$ & \\
\hline
\end{tabular}

According to the accounting personnel of the company, with the use of ERP system, their duty, monitoring the inventory, process transaction and report generation are now done with ease and accuracy. Since ERP systems create a single version of the information reports cannot be questioned because all members of the company are using the same system. 
Table 4 represents the level of effectiveness of SAP ERP in Universal Robina Corporation Calamba Plant. The over-all assessment of the respondents, SAP ERP is effective with the composite mean of 2.99. Respondents agreed that the use of SAP ERP system is utmost importance to a job with weighted mean of 3.21. This implies that a large number of respondents value the importance of SAP ERP to their work specification. The system is effective in its ability to execute a job without failure under any condition, with the lowest mean 2.71 .

Table 4. Level of effectiveness of SAP ERP in Universal Robina Corporation Calamba Plant

\begin{tabular}{|c|c|c|c|c|}
\hline & Indicators & WM & VI & Rank \\
\hline 1. & $\begin{array}{l}\text { System are easy to use and } \\
\text { navigate }\end{array}$ & 3.20 & $\mathrm{E}$ & 2 \\
\hline 2. & $\begin{array}{l}\text { System are genuine and } \\
\text { updated, such that when used } \\
\text { the result are free from error }\end{array}$ & 2.99 & $\mathrm{E}$ & 5 \\
\hline 3. & $\begin{array}{l}\text { System which I used enhances } \\
\text { my production of high quality } \\
\text { results }\end{array}$ & 2.98 & $\mathrm{E}$ & 6 \\
\hline 4. & $\begin{array}{l}\text { System has the ability to execute } \\
\text { a job without failure under any } \\
\text { condition }\end{array}$ & 2.71 & $\mathrm{E}$ & 10 \\
\hline 5. & $\begin{array}{l}\text { Through the use of the ERP system } \\
\text { in my workplace, I have been } \\
\text { able to finish my assigned task }\end{array}$ & 2.89 & $\mathrm{E}$ & 9 \\
\hline 6. & $\begin{array}{l}\text { Through the use of ERP system } \\
\text { in my workplace my work has } \\
\text { been faster, more accurate, } \\
\text { effective, efficient and reliable }\end{array}$ & 2.94 & $\mathrm{E}$ & 7 \\
\hline 7. & $\begin{array}{l}\text { The use of ERP system enhanced } \\
\text { and increased the quality and } \\
\text { quantity of my work }\end{array}$ & 3.00 & $\mathrm{E}$ & 4 \\
\hline 8. & $\begin{array}{l}\text { SAP ERP is of utmost importance } \\
\text { to my job }\end{array}$ & 3.21 & $\mathrm{E}$ & 1 \\
\hline 9. & $\begin{array}{l}\text { It takes less time and simple to } \\
\text { learn the various system process }\end{array}$ & 2.92 & $\mathrm{E}$ & 8 \\
\hline \multirow[t]{2}{*}{10.} & $\begin{array}{l}\text { System makes my job easy and } \\
\text { simple }\end{array}$ & 3.07 & $\mathrm{E}$ & 3 \\
\hline & Composite Mean & 2.99 & $\mathbf{E}$ & \\
\hline
\end{tabular}


According to the respondents, SAP ERP improves productivity, which is the main reason why Universal Robina Corporation applies it into their business processes. The respondents further agreed that the SAP ERP system has increases the pace of their work. The interconnectivity among all the modules of ERP systems reduces the time to perform the different operational tasks. ERP systems in Universal Robina Corporation used standard methods for automating some of the manufacturing process steps to save time, increase productivity, and reduce product cycle time.

SAP ERP system is the only one database that is easier for the staff to share and collect the data among various departments. For companies, improved cooperative working environment of each department and increased productivities are desirables result (Exforsys [11]).

Table 5 shows the problems encountered by respondents in the use of SAP ERP system. Having the composite mean of 1.92, the respondents agreed that Universal Robina Corporation is aware of possible occurrence of system implementation failure and that they are ready to handle such circumstances. Highest weighted mean of 2.45, the users sometimes encountered instability in network connection. On the other hand, with the lowest mean 1.65, respondents agreed that they do not finish the assigned task and verbally interpreted as sometimes. 
Table 5. Problems encountered by respondents in the use of SAP ERP system

\begin{tabular}{|c|c|c|c|c|}
\hline & Indicators & WM & VI & Rank \\
\hline 1. & Non Users friendly & 1.88 & $\mathrm{~S}$ & 6 \\
\hline 2. & $\begin{array}{l}\text { Does not finish the assigned task } \\
\text { on time }\end{array}$ & 1.65 & $\mathrm{~S}$ & 10 \\
\hline 3. & Delays of reports & 1.76 & $\mathrm{~S}$ & 8.5 \\
\hline 4. & Data in accuracy & 2.02 & $\mathrm{~S}$ & 3 \\
\hline 5. & Instability in network connection & 2.45 & $\mathrm{~S}$ & 1 \\
\hline 6. & $\begin{array}{l}\text { Cost maintenance and upgrading } \\
\text { services }\end{array}$ & 1.92 & $\mathrm{~S}$ & 4 \\
\hline 7. & $\begin{array}{l}\text { Problems of security and } \\
\text { confidentiality }\end{array}$ & 1.76 & $\mathrm{~S}$ & 8.5 \\
\hline 8. & Data appear to be time consuming & 2.04 & $\mathrm{~S}$ & 2 \\
\hline 9. & Hardware malfunction & 1.91 & $\mathrm{~S}$ & 5 \\
\hline 10. & Software failure & 1.84 & $\mathrm{~S}$ & 7 \\
\hline & Composite Mean & 1.92 & $\mathbf{S}$ & \\
\hline
\end{tabular}

Table 6 shows the difference on the effectiveness of SAP ERP in Universal Robina Corporation when grouped according to profile variables. Based from the table, the computed $\mathrm{F}_{\mathrm{c}}$-values of the profile variables civil status and years of experience were all greater than the critical value and the resulted $p$-values were less than 0.05 level of significance, thus, the null hypothesis of no significant difference on the effectiveness in the use of SAP ERP system when grouped according to the mentioned profile variables is rejected. This means that significant differences exist and that respondents have assessed their effectiveness in the use of ERP SAP system when grouped according to the mentioned profile variables differently. This means that the respondents whether single or married have been in the company for less than a year or more and have assessed their effectiveness in the use of the said system distinctly. The profile variable educational attainment has no value because the respondents were singly categorized as bachelors degree graduate. 
The above result may be explained through the definition of learning. Learning is the activity or process of gaining knowledge or skill by studying, practicing, being taught, or experience of individual. A person's knowledge is a result of experience, and no two people have identical experiences. Even when observing the same event, two people react differently; they learn different things from it, according to the manner in which the situation affects their individual needs. Previous experience conditions a person to respond to something and to ignore others (www.dynamicflight.com/avcfibook/learning_process/).

Table 6. Difference on the effectiveness of SAP ERP in Universal Robina Corporation when grouped according to profile variables

\begin{tabular}{ccc}
\hline Profile variables & $\mathbf{F}_{\mathbf{c}}$ & $\boldsymbol{p}$-value \\
\hline Age & 2.044 & 0.096 \\
Gender & 1.447 & 0.232 \\
Civil Status & 4.462 & $0.038^{*}$ \\
Educational Attainment & $\ldots \ldots . .$. & $\ldots . . . .$. \\
Years of Experience & 4.152 & $0.009^{*}$ \\
Department & 1.717 & 0.128 \\
Module & 1.717 & 0.128 \\
\hline
\end{tabular}

Legend: *Significant at p-value $<0.05$. 
Table 7. Proposed strategies to enhance the effectiveness of the SAP ERP system in Universal Robina Corporation Calamba Plant

\begin{tabular}{llll}
\hline \multicolumn{1}{c}{ Key result area } & \multicolumn{1}{c}{ Strategies } & \multicolumn{1}{c}{ Persons involved } \\
\hline $\begin{array}{l}\text { Ability to execute a job } \\
\text { without failure under } \\
\text { any condition }\end{array}$ & $\begin{array}{l}\text { Maintain a robust and adopt reliable } \\
\text { technological infrastructure }\end{array}$ & $\begin{array}{l}\text { Information System } \\
\text { Division (ISD) HR, All } \\
\text { Departments }\end{array}$ \\
\hline Finish assigned task & $\begin{array}{l}\text { Provide training program across the } \\
\text { organization to ensure full utilization } \\
\text { of technology and improve users } \\
\text { proficiency in the use of SAP system }\end{array}$ & $\begin{array}{l}\text { CORPlan, Information } \\
\text { System Division (ISD), } \\
\text { Departments }\end{array}$ \\
\hline $\begin{array}{l}\text { Less time and simple to } \\
\text { learn the various system } \\
\text { process }\end{array}$ & $\begin{array}{l}\text { Provide pervasive and easy to use } \\
\text { access to information for employees } \\
\text { and direct access to information from } \\
\text { their mobile devices. }\end{array}$ & $\begin{array}{l}\text { Information } \\
\text { Division (ISD) }\end{array}$ & System \\
\hline $\begin{array}{l}\text { Work has been faster, } \\
\text { more accurate, effective, } \\
\text { efficient and reliable }\end{array}$ & $\begin{array}{l}\text { Establish standards to achieve } \\
\text { consistency and high quality of } \\
\text { software through systematic and } \\
\text { rigorous engineering }\end{array}$ & $\begin{array}{l}\text { Information } \\
\text { Division (ISD) CORPlan }\end{array}$ & System \\
\hline $\begin{array}{l}\text { Enhances my production } \\
\text { of high quality result }\end{array}$ & $\begin{array}{l}\text { Accelerating test cycles, detecting and } \\
\text { resolving key problems that impact } \\
\text { business performance, and increased } \\
\text { business performance. }\end{array}$ & $\begin{array}{l}\text { Information Division } \\
\text { Departments }\end{array}$ & System \\
\hline
\end{tabular}

\section{Conclusion and Recommendation}

The SAP ERP system users of Universal Robina Corporation Calamba Plant are mostly female, graduate of Bachelors Degree and regular employees. The SAP ERP system in Universal Robina Corporation is effective with respect to software implementation and performance. Measures to enhance level of effectiveness of the SAP ERP system in Universal Robina Corporation Calamba Plant have been proposed.

It is recommended that the company may clearly define what positive results can be expected from the use of the ERP system before or during ERP implementation and provide training opportunities on a continuous basis to meet the changing needs of the business and employees. Further enhancement in all aspects of SAP ERP system may be undertaken through by continuing research on ERP functionality in order to identify and achieve the expected benefit. To make the ERP system more useful, the company may focus more on enhancing the quality of output during its implementation, especially regarding to the management reports and measurement reports. 
The proposed measures may be tabled for discussion by the management and may be implemented. Future researchers may conduct similar study but may consider other variables not included in this study.

\section{References}

[1] S. M. Arachchi, ERP fail, ict3001, enterprise resource planning, University of Colombo School of Computing, 2014, Panorama Consulting Solutions 2010 ER REPORT: A Panorama Consulting Solutions Research Report.

[2] G. R. Dantes and A. H. Zainal, The Relationship of Organization Maturity Level and Enterprise Resource Planning (ERP) Adoption (Case Study: ERP Implementation in Indonesian Companies), Proceedings of the 14th International Business Information Management Association Conference, June 23-24, 2009, Istanbul, Turkey, ISBN: 978-0- 9821489- 3-8, 2444-2456, (2010).

[3] B. Johansson, Pain Points Challenges for future Enterprise Resource Planning (ERP) system 2007, www.3gerp.or. November 24th 2009 (2007).

[4] B. Johansson and F. Sudzina, Choosing open source ERP systems: What reason are there for doing so? FIP AICT 299 (2009), 143-155.

[5] K. C. Laudon and J. P. Laudon, Management Information Systems: Managing the Digital Firm, 12th Edition, New Jersey: Pearson, 2012.

[6] G. C. Peng and M. B. Nunes, Identification and assessment of risks associated with ERP post implementation in China, Journal of Enterprise Information Management 22(5) (2009), 587-614.

[7] SAP ERP, Accessed 3 May 2011.

http://www.sap.com/solutions/businesssuite/erp/featuresfunctions/index.epx

[8] R. Addo-Tenkorang and P. Helo, Enterprise resource planning (ERP): A review literature report, Proceedings of the World Congress of Engineering and Computer Science 2 (2011), 19-21.

[9] O. Prokopiev and I. Sevostianov, Dependence of the mechanical properties of sintered hydroxyapatite on the sintering temperature, Materals Science and Engineering: A 431(1) (2006), 218-227.

[10] S. Wei, Q. Zhou and P. V. Koval, Flowering stage characteristics of cadmium hyperaccumulator solanum nigrum L. and their significance to phytoremediation, Science of the Total Environment 369(1) (2006), 441-446.

[11] Exforsys, Service Orientation and Interoperability.

http://www.exforsys.com/tutorials/soa/service-orientation-and-interoperability.html 